\author{
Anna Kizińska \\ University of Warsaw, Poland
}

\title{
TRANSLATION METHODS APPLIED TO APPROACH THE INCONGRUITY OF TERMS IN POLISH AND BRITISH CRIMINAL LAW
}

\begin{abstract}
Summary. The research analyses incongruent Polish and British criminal law terms. British terms are the names of legal institutions characteristic of three independent legal systems: of England and Wales, Scotland or Northern Ireland. The Polish terms that have been discussed come from the Polish Criminal Code Act of 6 June 1997 (Journal of Laws 1997 No. 88 item 553). Moreover, they are legal terms pursuant to their interpretation by Morawski (1980, p. 187). The English equivalents under analysis have appeared in four Polish Criminal Code translations into English. The research aims at a verification of whether or not the classification of translation methods applied in the Polish-English translation of incongruent succession and family law terms (called civil law terms) (Kizińska, 2015, p. 175-178) encompasses translation methods used in the process of translation of incongruent law terms characteristic of criminal law into English. In the paper the translation method is interpreted according to the definition by Hejwowski $(2004$, p. 76). In the theoretical part of the paper the following linguistic phenomena have been presented: a term (by Zmarzer \& Lukszyn, 2001, p. 9) and incongruity of terms (by Šarčević, 1989, p. 278). In the initial stage of the analysis the definitions of a given Polish term and its suggested equivalents have been compared. Next, the appearance of a given equivalent in the sources of British law texts as well as the English language has been checked to determine the translation methods used while forming a given equivalent. Finally, the list of translation methods applied has been drafted, to conclude, among other things, that the translation methods presented in the above-mentioned typology of translation methods applied in the translation of incongruent civil law terms from Polish into English are to be determined as exclusively primary or secondary.
\end{abstract}

Keywords: civil law; equivalence; incongruent terms; Polish criminal law; translation methods.

\section{Introduction}

For translators who are professionally engaged in Polish-English legal translation it is of primary importance to be able to successfully deal with the translation of specialist vocabulary that names institutions typical for a given legal system (called system-bound terms by Šarčević, 1997, p. 232). It should be emphasised that deciding which of the equivalents suggested in dictionaries is the most appropriate one may be very demanding. The activity seems arduous because the Polish legal system is one of civil law systems, whereas the legal system encompassing those of England and Wales, 
Scotland and Northern Ireland (here called the British legal system) belongs to a group of common law systems. What is more, the United Kingdom of Great Britain and Northern Ireland has no unified legal system. England and Wales have one common legal system, while Scotland and Northern Ireland have separate legal systems. In the research, the terminology that names the legal institutions of the legal systems of England and Wales, Scotland and Northern Ireland is called British legal system terms.

Kizińska (2015, pp. 175-178) drew up a classification of translation methods that are applied in the process of translation of incongruent succession and family law terms from Polish into English. The research aims to verify whether or not the classification encompasses translation methods used in the process of Polish-English translation of incongruent law terms characteristic of criminal law. The above-mentioned classification is one of the translation method classifications applied while translating legal terms drawn up worldwide - Kovacs (1982, pp. 83-100), Weston (1993, pp. 4151), Harvey (2003, pp. 1-9). The typology by Kizińska (2015, pp. 175-178) was applied in the research project as precisely this typology refers to the incongruent terms in Polish-English translation. The research project presented here encompasses an analysis of over fifty Polish criminal law terms and their English equivalents. It should be emphasised that the reference point in the analysis is the so-called British legal system because the typology of methods has been drawn up in connection with research where the aforementioned system was the frame of reference.

\section{Theoretical Overview}

The terms naming criminal law institutions of the Polish legal system analysed in the research are terms interpreted pursuant to the definition of Sager (1990, p. 19), namely: "The items which are characterised by special reference within a discipline are the terms of that discipline (...)". What is more, they constitute terms according to the interpretation of Lukszyn and Zmarzer: "a word (a phrase) of a conventionally determined, strictly defined conceptual structure, as a rule monosemic and uninterpretable, of an emotional character, able to create systems" (2001, p. 9). The analysed 
Polish terms serve as legal terms defined by Morawski (1980, p. 187) who states that legal terms are just terms appearing in normative texts as long as the application criteria thereof have been regulated by the law in the form of legal definitions. Normative texts are defined in the research pursuant to the definition by Gizbert-Studnicki (1986, pp. 95-102). The terms analysed in the research project have been excerpted from the Polish Criminal Code Act of 6 June 1997. The English equivalents of the Polish source terms discussed in the paper have been used by translators that have produced as many as four Polish Criminal Code Act translations into English published between the years 1997 and 2014 (their bibliographical details have been presented in the reference list below).

The research consists of the following stages: 1 ) citing a definition of a given source term (whose sources are Polish Criminal Code coursebooks, Criminal Code commentaries), 2) presenting a list of the English equivalents of the source term as well as a consideration of the similarities and dissimilarities of the legal institutions they name on the basis of the definitions thereof (as long as the equivalents have been accommodated in English law dictionaries presented in the reference list below) and the institution named by the Polish source term, 3) checking if a given suggested equivalent occurs in the texts of sources of British law (i.e., the legislation.gov.uk database) and the general English corpora of sketchengine.eu that encompasses five hundred corpora. The last stage involves determining the translation method used to produce a given English equivalent. Translation method is interpreted according to Hejwowski (2004, p. 76): "a given type of action undertaken during a translation process, as well as a given translation solution, the implementation of which may be evaluated directly in a target text".

\section{Methods of Translation (Reference Point)}

The typology in question published in 2015 (Kizińska, 2015, pp. 175-178) categorises translation methods of the incongruent Polish-English civil law terms translation in the following manner: 
1) functional equivalent method by Hejwowski (2004, p. 81) that "involves replacing the name of a phenomenon (or a reference thereto) which is more commonly known in the source culture with the name of a phenomenon (a reference thereto) which is more commonly known in the target culture" (Kizińska, 2019, p. 112);

2) hypernym method means "replacing a hyponym in the source text with a hypernym in the target text" (Kizińska, 2019, p. 113);

3) hyponym method entails "replacing a hypernym in the source text with a hyponym in the target text" (Kizińska, 2019, p. 113);

4) descriptive equivalent method by Hejwowski involves "replacing a term with a description or a definition" (Kizińska, 2019, p. 113);

5) partial semantic shift method entails "using a phrase from the target language in the target text that appears in the texts of the sources of law of the target language, the meaning of which is partially different from the meaning of the phrase from the source language that appears in the texts of the sources of law of the source language. As a result, the meaning of the phrase of the target language in the target text is partially changed" (Kizińska, 2019, p. 113);

6) complete semantic shift method involves "using a phrase from the target language in the target text that appears in the texts of the sources of law of the target language the meaning of which is completely different from the meaning of the phrase from the source language that appears in the texts of the sources of law of the source language. As a result, the meaning of the phrase of the target language in the target text is changed" (Kizińska, 2019, p. 113);

7) terminologisation method means "using in the target text a phrase that appears in the target language but is not a legal term. The result of its application means a phrase of general language becoming a legal term in the target language; an equivalent appears in English texts but does not signify a legal institution" (Kizińska, 2019, p. 113);

8) calque method "that encompasses the calque method or procedure by Vinay and Darbelnet $(1958 / 2000$, p. 85$)$, the translation procedure by Newmark (1988, p. 70) called calque, as well as partially the calque and loan strategies by Chesterman (1997, p. 8991). As a result new phrases that do not appear in the target language are formed" (Kizińska, 2019, p. 113);

9) transposition method that means "replacing one part of speech by another" (Kizińska, 2019, p. 113);

10) translation doublet entailing "a) the replacement of a source term with two descriptive equivalents in the target text (the second of the descriptive equivalents used is in the round brackets in the target text); or b) replacing a source term with two equivalents in the target text that have been formed with the application of two methods where the second equivalent (that is in the round or square brackets, or partially in round brackets) has been formed with the application 
of the functional equivalent method or descriptive equivalent method" (Kizińska, 2019, p. 113);

11) recognized translation method by Newmark (1988, p. 92) "which is of secondary character in comparison with methods $1-9$, as each equivalent to be widely used (and thus acquiring the status of a recognized translation) must have been formed with the application of one or more of methods 1-9" (Kizińska, 2019, p. 114).

It should be underlined that the term functional equivalent has been so far interpreted differently in literature (e.g., Reiss \& Vermeer, 1984). The definition by Šarčević is: "a term designating a concept or institution of the target legal system having the same function as a particular concept of the source legal system" (1997, p. 236). "Finding a functional equivalent is the first step in the decision-making process (...). In order to determine the acceptability of a functional equivalent, translators must compare the target and source concepts to establish their degree of equivalence" (Pigeon, 1982, p. 280 in Šarčević, 1997, p. 236).

\section{Methodology}

Over fifty criminal law terms (in the Polish Criminal Code Act of 6 June) randomly selected among those for which more than two different equivalents have been suggested in the Polish Code translations into English (drawn up between 1997 and 2014) are analysed in the research. What is more, the terms mentioned constitute conceptually incongruent terms according to the definition by Šarčević (1997, p. 232). "Due to the conceptual incongruency of terminology of different legal systems, it is sometimes extremely difficult to select equivalents that will guarantee uniform interpretation and application of the propositional content of a legal norm" (Šarčević, 1997, p. 149). The concept of conceptually incongruent terms is directly connected with the phenomenon of the so-called incongruity of terms, i.e. non-coincidence of their semantic fields (Šarčević, 1997, p. 278). What is extremely challenging for Polish-English legal text translators is that the specialist vocabulary naming legal institutions typical of different legal systems is to a large extent conceptually incongruent. 


\section{Analysis}

The analysis presented below has involved identifying translation methods applied in forming English equivalents of 50 Polish terms. The table below presents eight Polish terms discussed that serve as a research sample to present each and every translation method that has been applied in the formation of as many as 135 equivalents of the Polish terms under analysis.

Table 1

Polish Terms and Their Equivalents

\begin{tabular}{lllll}
\hline Polish term & $\begin{array}{l}\text { Criminal Code } \\
(\mathbf{1 9 9 7 )}\end{array}$ & $\begin{array}{l}\text { kozińska- } \\
\text { Małkiewicz } \\
\mathbf{( 2 0 0 8 )}\end{array}$ & $\begin{array}{l}\text { Faulkner } \\
\mathbf{( 2 0 1 2 )}\end{array}$ & $\begin{array}{l}\text { Wojtaszczyk, } \\
\text { Zontek (2014) }\end{array}$ \\
\hline przedawnienie & $\begin{array}{l}\text { statutes of } \\
\text { limitation }\end{array}$ & $\begin{array}{l}\text { statute of } \\
\text { limitation }\end{array}$ & $\begin{array}{l}\text { statutes of } \\
\text { limitation }\end{array}$ & prescription \\
\hline ciag przestępstw & $\begin{array}{l}\text { series of } \\
\text { offences }\end{array}$ & $\begin{array}{l}\text { sequence of } \\
\text { offences }\end{array}$ & $\begin{array}{l}\text { series of } \\
\text { offences }\end{array}$ & sequence of crimes \\
\hline kara łączna & $\begin{array}{l}\text { aggregate } \\
\text { penalty }\end{array}$ & $\begin{array}{l}\text { cumulative } \\
\text { penalty }\end{array}$ & $\begin{array}{l}\text { cumulative } \\
\text { penalty }\end{array}$ & aggregate penalty \\
\hline $\begin{array}{l}\text { korzyść } \\
\text { majatkowa }\end{array}$ & $\begin{array}{l}\text { material } \\
\text { benefit }\end{array}$ & $\begin{array}{l}\text { material } \\
\text { benefit }\end{array}$ & $\begin{array}{l}\text { material } \\
\text { benefit }\end{array}$ & $\begin{array}{l}\text { material benefit } \\
\text { financial benefit }\end{array}$ \\
\hline kara grzywny & fine & fine & fine & fine \\
\hline podżeganie & instigating & $\begin{array}{l}\text { instigation to } \\
\text { offence }\end{array}$ & instigation & incitement \\
\hline przepadek & forfeiture of & forfeiture of & forfeiture & forfeiture of items \\
objects & of items & \\
\hline items & next of kin & next of kin & next of kin & $\begin{array}{l}\text { immediate family } \\
\text { member }\end{array}$ \\
\hline
\end{tabular}

\section{Przedawnienie}

Another Polish term under analysis is przedawnienie defined as a circumstance under which the punishability of a crime is eliminated by virtue of the law due to the lapse of time (Daniluk et al., 2018, p. 240). 
The periods of time determined have been laid down in Article $101 \S 1$ for crimes prosecuted upon a public complaint and $101 \S 2$ for crimes prosecuted upon a private complaint (Daniluk et al., 2018, p. 241). The equivalents of the term przedawnienie - statute of limitations and statute of limitation both serve as functional equivalents of the Polish source term as they name the idea of a legal claim becoming unclaimable due to the lapse of a given period of time. Undoubtedly, the time limits for various offences differ in the two legal systems under discussion. The first equivalent, statute of limitations, is defined in Council Decision of 25 September 2008 on the conclusion, on behalf of the European Community, of the United Nations Convention against Corruption (2008/801/EC) as:

\begin{abstract}
Each State Party shall, where appropriate, establish under its domestic law a long statute of limitations period in which to commence proceedings for any offence established in accordance with this Convention and establish a longer statute of limitations period or provide for the suspension of the statute of limitations where the alleged offender has evaded the administration of justice.
\end{abstract}

The equivalent statute of limitations, however, does not appear in the dictionaries of law. The second term, statute of limitation, is, on the other hand, defined in Jowitt's Dictionary of English Law: "Time limits upon the bringing of legal proceedings" (2015, p. 1433). It should be underlined that the terms limitations of actions and statute of limitation are synonyms of the discussed statutes of limitation (Jowitt's Dictionary of English Law, 2015, p. 1433, 2299).

Another equivalent for the Polish przedawnienie is prescription defined in Jowitt's Dictionary of English Law as follows: "where a right, immunity or obligation exists by reason of lapse of time (...) the only property that can be acquired through prescription are incorporeal hereditaments" (2015, p. 1885). Another definition of the term is: "A title may be established by prescription in any of three ways: first, prescription at common law; secondly, prescription under the doctrine of a lost modern grant; and thirdly prescription as governed by the provisions of the Prescription Act 1832". The equivalent discussed does not name any legal institution in the target legal culture similar to the institution of the source target culture named with 
the source term. The equivalent has been formed with the complete semantic shift translation method as it constitutes a legal term in the target culture but of a completely different meaning than the source term. The equivalent discussed does not mean a circumstance under which the punishability of a crime is eliminated by virtue of the law due to the lapse of time.

\section{Ciąg przestępstw}

Another term under analysis is ciąg przestępstw that involves a situation where a perpetrator commits at least two crimes within a short period of time and before the first verdict (not even a final one) is pronounced. In the case of a so-called series of offences one cumulative penalty is pronounced and imposed. In the translations of the Polish Criminal Code as many as three equivalents have been produced: sequence of offences/crimes and series of offences. The last term, namely, series (also called series of offences - as provided for in The Criminal Procedure Rules 2012 Section 14.2.) is defined as: "charges for any offences might be joint in the same indictment if those charges were founded on the same facts, or formed part of a series (...) two offences could constitute a series (...)" (2007, p. 935). Series, however, appears in various sources of British law with different meanings, e.g., in The Road Vehicles (Approval) Regulations 2009 it appears in the following context: "Applications for national small series type approval 24 . (1) A vehicle manufacturer requiring- (a) a national small series type approval in respect of a relevant vehicle, or (b) an amendment to a national small series type approval which the manufacturer holds, must apply to the approval authority". As the Polish term names a criminal law term exclusively and series is characterised by more than one meaning, the equivalent is a hypernym of the source term.

As a result of the fact that the equivalents sequence of offences/crimes do not appear in the texts of the sources of British law or Jowitt's Dictionary of English Law but do appear in the corpora of the English language, they are assumed to have probably been formed as a result of the terminologisation method. 


\title{
Kara łączna
}

The analysed Polish term refers to a penalty that is pronounced in a situation where a series of crimes has occurred and at the same time the penalties pronounced are of the same type or may be combined under the specific regulations. The aim of such a penalty being pronounced is the rationalisation of a criminal repression (Daniluk et al., 2018, p. 87).

Two equivalents suggested do not appear in the British law dictionaries. The first one is aggregate penalty. It appears in British legislation regarding finance, insurance and carrier liability but not criminal law. What is more, the equivalent aggregate penalty is defined in the Finance Act 2016:

\begin{abstract}
Aggregate penalties 8 (1) Sub-paragraph (3) applies where-(a) two or more penalties are incurred by the same person and fall to be determined by reference to an amount of tax to which that person is chargeable, (b) one of those penalties is incurred under section $212 \mathrm{~A}$, and (c) one or more of the other penalties are incurred under a relevant penalty provision.
\end{abstract}

The term also appears in the general English corpora. As the equivalent in question has acquired in texts of law (UK) a meaning that is different from the semantic field of the Polish source term, the equivalent has probably been formed as a result of the application of the complete semantic shift method. The same refers to the equivalent cumulative penalty that also appears in two documents of British legislation, namely the Game Act 1831 and the Clean Air Act 1993. In the last document a quasi-definition of the equivalent appears:

Cumulative penalties on continuance of certain offences. (1) Where(a) a person is convicted of an offence which is subject to cumulative penalties on continuance in accordance with this section; and (b) it is shown to the satisfaction of the court that the offence was substantially a repetition or continuation of an earlier offence by him after he had been convicted of the earlier offence, the penalty provided by subsection (2) shall apply instead of the penalty otherwise specified for the offence.

On the basis of the Game Act 1831 no definition of the term in question may 
be formed. Taking the above into account it may be assumed that the equivalent has also been formed with the complete semantic shift translation method.

\section{Korzyść majątkowa}

Material benefit or personal benefit is a benefit for themselves as well as for somebody else (Article 115 of the Polish Criminal Code).

A material benefit may involve enlarging a person's property, for example via an acquisition of money or valuables or a decrease in liabilities or the execution of a profitable agreement including an interest-free loan agreement.

In the Polish Code translations into English, two equivalents have appeared, namely material benefit and financial benefit. The first equivalent does not appear in the English dictionaries of law. It does appear in the texts of the sources of law, e.g., "Material benefits comprise any benefits by way of pension, allowance, lump sum or gratuity expected to be paid when the person has attained the age of 60 and whose actuarial equivalent as an annuity for life from that age would be more than $£ 260$ a year" in The Teachers' Pensions Regulations 1997. In the cited context the equivalent names a type of legal profit gained on a specific basis.

It should be emphasised that in the EU-related UK sources of law the lexical field of the term discussed encompasses the meaning of a profit gained illegally in specific situations as appears in the following context: "Criminalisation: 1. Each State Party shall adopt such legislative and other measures as may be necessary to establish as criminal offences, when committed intentionally and in order to obtain, directly or indirectly, a financial or other material benefit: (a) the smuggling of migrants (...)." [Council Decision of 24 July 2006 (...) (2006/616/EC)]. Summing up, the lexical field of the equivalent under analysis is more extensive than that of the source term, thus it has been formed as a result of the application of the hypernym method.

Another equivalent has not been accommodated in the English law dictionaries either, but it does appear in the texts of doctrine and numerous 
texts of sources of British law among which there is a legislative act referring to criminal law, namely: The Criminal Procedure (Amendment No. 2) Rules 2013. In the text mentioned, the details on the application to get a proposal to enter into an agreement approved have been described. In the application there should be included, among others, the details of any surrender of profits or other financial benefit by the defendant, and the time within which any such sum is to be surrendered. According to the definition of the partial shift translation method presented above, the equivalent discussed has been formulated as a result of the application of this method, as its semantic field does not overlap that of the source term, but still the equivalent appears in texts of the sources of British law in a text on criminal law matters.

\section{Kara grzywny}

There has been only one equivalent suggested in all translations of the Polish Criminal Code published between the years 1997 and 2014, namely fine, so it constitutes a recognized equivalent as defined above. As far as the primary translation method that has been used to formulate this widely used equivalent is concerned, it may be assumed, on the basis of the following definitions, that the equivalent discussed is a hyponym of the source term. The English equivalent has a more extensive meaning than the Polish source term as it encompasses both monetary and non-monetary compensation in the case of a conviction. The Polish term names a measure of criminal legal reactions, the essence of which is the obligation to pay a given amount of money to the benefit of the State Treasury (Daniluk et al., 2018, pp. 83-84). The term fine is defined in Jowitt's Dictionary of English Law: "in criminal law, a fine is a sum of money ordered to be paid to the Crown by an offender, as a punishment for his offence" (2015, p. 986). The equivalent has also been accommodated in Words and Phrases Legally Defined (Hay, 2007, p. 937): "a) any pecuniary penalty, pecuniary forfeiture of pecuniary compensation payable under a conviction, and any non-pecuniary forfeiture on conviction by, or under any order of, a magistrates' court so far as the forfeiture is converted into or consists of money". 


\section{Podżeganie}

Podżeganie is defined as a non-causative (indirect) form of committing an illicit act, the essence of which is convincing somebody to commit an illicit act. Podżeganie involves influencing a person's psyche to make them decide to commit an illicit act. Podżeganie takes place exclusively by an act (not an omission) and occurs prior to the commission of an illicit act (Daniluk et al., 2018, p. 224).

As many as four equivalents have been used to translate the discussed form of committing an illicit act: incitement, instigation, instigating, instigation to offence. The first one is defined as "the act of urging or provoking to a course of criminal action. It is a common law offence for one person to incite another to commit an offence (Dictionary of Law, 2002 , p. 210). The term incitement probably serves as the functional equivalent of the Polish term but still the punishments for the legal phenomena podżeganie and incitement as well as the types of acts are different in the legal systems under discussion. As far as the types are concerned, it is worth mentioning a source of law text, namely the Incitement to Disaffection Act 1934, is aimed at stopping people who divert members of the armed forces from their duties.

The equivalent instigation according to Jowitt's Dictionary of English Law (2015, p. 1267) "is not a term of art in relation to the criminal law in the same way as incitement, it is found in occasional use in statute in framing offences and is to be construed as an aspect of sub-class of incitement". It may be assumed that instigation has a more limited lexical field than podżeganie as an act of instigation is only a type of the legal institution called incitement which has just been stated to serve as a functional equivalent of the Polish term in question. Probably the equivalent has been formed using the hyponym translation method (the hyponym method involves replacing a hypernym in the source text with a hyponym in the target text). Both suggested equivalents appear in English law dictionaries and sources of normative texts.

The equivalent instigating has been formed again with the hyponym method but together with the transposition method which is a secondary 
method (involving replacing a noun by a gerund verb form).

The equivalent instigation to offence has been formed with a hyponym method as the term instigation constitutes an element thereof and a calque method as the whole expression does not appear in the corpora of the English language.

\section{Przepadek}

Another Polish term under discussion is przepadek, a type of penal measure under the Polish legal system (Mozgawa, 2019, p. 249). The Polish term is defined as a repression instrument of a monetary character aiming at depriving a criminal of the opportunity to gain benefits directly or indirectly from a crime (Mozgawa, 2019, p. 251). There have been two English equivalents used in the Polish Criminal Code translations into English, namely: forfeiture of objects and forfeiture of items.

The first equivalent appears in the texts of the sources of British law and its element, namely forfeiture, names situations "where a person loses some property, right, privilege or benefit in consequence of having done or omitted to do a certain act" and where "property used for the purpose of committing or facilitating the commission, of a crime, or which was intended for that purpose, may be made the subject of an order depriving the offender of his rights, if any, in the property and the property may be taken into the possession of the police or detained by them (...)" as well as "a form of punishment in criminal cases" in Jowitt's Dictionary of English Law (2015, pp. 1015-1017). This element has been formed with the hypernym translation method while translating the Polish term in question into English. Summing up, while forming the equivalent forfeiture of objects a hypernym method (as far as the element forfeiture is concerned) and the partial semantic shift translation method have been used since the whole equivalent appears in the sources of British law of criminal law.

Another equivalent, forfeiture of items, appears in the sources of British law but not criminal law documents. Thus, it has been formed with the use of the hypernym method (as far as the element forfeiture is concerned) and the complete semantic shift translation method. 


\section{Osoba najbliższa}

The last analysed term is osoba najbliższa defined as "a spouse, a descendant, an ancestor, siblings and persons related by affinity in the same line and degree, a person being in an adoptive relationship and a spouse thereof, as well as a person in factual cohabitation therewith" (Daniluk \& et al., 2018, p. 203). Next of kin is "a person's closest blood relations. Parents and children are treated as being closer than grandparents, grandchildren, or siblings" (A Dictionary of Law, 2003, p. 329). "Those who are next in degree of kindred to a deceased person, i.e., are most closely related to him in the same degree" (Jowitt's Dictionary of English Law, 2015, p. 1631). After the thorough analysis of the quoted definitions, it may be stated that the semantic fields of the source term (osoba najbliższa) and the equivalent (next of kin) coincide to a non-significant degree as the definition of the source term is very detailed and presents a complete list of persons who are assumed to be osoba najbliższa. The two definitions of the equivalent differ from each other, referring, among others, to people closely related to a deceased person (while the definition of the source term does not) and they do not list people by affinity as being the next of kin (whom the definition of the source term includes). Taking the above into account, the equivalent has probably been formulated with the application of the partial semantic shift translation method. The semantic fields of the source and the equivalent do not coincide as far as the principal feature is concerned, namely the source term names just closest blood relatives while the equivalent refers to the closest blood relatives of a deceased person exclusively. It should be stated that the equivalent appears in one text of the sources of British law.

The equivalent immediate family member has probably been formulated with the application of the partial semantic shift as the equivalent appears in a text being a source of British law but not a source of criminal law.

\section{Conclusions}

On the basis of the analysis of 135 English equivalents of the Polish criminal 
law terms it may be concluded that, firstly, 10 out of 11 translation methods presented above (used to translate incongruent civil law Polish terms into English) are applicable while translating incongruent Polish criminal law terms into English. Presented below are the translation methods mentioned together with the equivalents that have been formed with the application thereof: 1) the functional equivalent method by Hejwowski has been used to form equivalents such as punitive damages, compensatory damages, exemplary damages; 2) the hypernym method has been used exclusively (together with no other translation methods) to form equivalents such as community work, series of offences, fine, juvenile; 3 ) the hyponym method has been exclusively used to form equivalents such as release on licence, riot; 4) the descriptive equivalent method by Hejwowski has been used exclusively in the case of the equivalent work for the good of others and together with the hyponym translation method in the case of the equivalent larceny by breaking; 5) the partial semantic shift method has been exclusively used while forming, among others, next of kin, perpetration, substantial material damage; and together with the hypernym method in the case of the equivalent forfeiture of objects; 6 ) the complete semantic shift method has been exclusively used while forming equivalents such as aggregate penalty, absolute necessity, penal measure as well as together with the hypernym translation method in the case of the forfeiture of items equivalent; 7) the terminologisation method has been exclusively used while forming, among others, the equivalent significant material damage and together with the hypernym translation method while forming the equivalent theft by breaking; 8) the calque method has been exclusively used while forming, among others, limitation of liberty, monetary performance, work for community; together with hyponym method - instigation to offence 9) the transposition method has not been used exclusively, but together with the hyponym translation method while forming the equivalent instigating; together with the calque method - to enforce the collection of a claim, and together with the complete semantic shift method - to enforce a claim; 10) the recognized translation method by Newmark has been used, among others, in the case of the fine or preparation equivalents.

Secondly, the transposition method (involving replacing one part of 
speech with another) as well as translation doublet have been assumed to be methods of a secondary character because of the fact that, in order to conclude that an equivalent constitutes a different part of speech than the source term, it is necessary to previously form the equivalent in question by applying one of the remaining methods classified above (of a primary character).

Thirdly, among the equivalents analysed there are phrases during the formation of which more than one primary translation method has been simultaneously applied: a) the partial shift translation method together with the hypernym method; b) the complete shift translation method together with the hypernym method; c) the hypernym together with the terminologisation method; d) the hyponym plus the descriptive equivalent; e) the hyponym method together with the calque method.

Fourthly, there are phrases during the formation of which one primary translation method together with one secondary translation method have been simultaneously applied: instigating (the hyponym together with the transposition method), fine (the hyponym together with the recognised equivalent); to enforce a claim (wymuszenie wierzytelności) - the complete semantic shift together with the transposition method; to enforce the collection of a claim (wymuszenie wierzytelności) - the calque method together with the transposition method.

Last but not least, some descriptive equivalents may at the same time be assumed to be equivalents formulated with the application of the terminologisation method. What is more, not each and every terminologisation method equivalent constitutes a descriptive equivalent, but each and every descriptive equivalent is a terminologisation equivalent. Thus, it may be assumed that in some cases the descriptive equivalent method serves as a secondary translation method.

\section{References}

Anonymous. (1997). Penal code of Poland (Act of 6 June 1997). Warsaw.

Chesterman, A. (1997). Memes of translation: The spread of ideas in translation theory. John Benjamins Publishing. 
Daniluk, P., Gensikowski, P., Kuczyńska, H., Kulesza, J., Kulik, M., \& Leciak, M. (2018). Leksykon prawa karnego - część ogólna. 100 podstawowych pojęć. C. H. Beck.

Faulkner, N. (2012). The criminal code. Bilingual edition. C.H. Beck.

Gizbert-Studnicki, T. (1986). Język prawny z perspektywy socjolingwistycznej. Zeszyty Naukowe Uniwersytetu Jagiellońskiego. Prace z nauk politycznych, 26, 95-102.

Harvey, M. (2008). A beginner's course in legal translation: The case of culture-bound terms. http://www.tradulex.com/Actes2000/ harvey.pdf

Hejwowski, K. (2008). Kognitywno-komunikacyjna teoria przekładu. PWN.

Jopek-Bosiacka, A. (2008). Przekład prawny i sądowy. PWN.

Kizińska A., (2015). Ekwiwalencja w tłumaczeniu tekstów prawnych i prawniczych. Polskie i brytyjskie prawo spadkowe. C. H. Beck.

Kizińska, A. (2019). Polskie i angielskie terminy nieprzystające. Prawo rodzinne i spadkowe. C. H. Beck.

Kovacs, A. (1982). La réalisation de la version francaise des lois fédérales du Canada. In J. C. Gémar (Ed.), Langage du droit et traduction (pp. 83100). Éditeur officiel du Québec.

Łozińska-Małkiewicz, E. (2008). Kodeks karny. The penal code. Wydawnictwo Ewa.

Lukszyn, J., \& Zmarzer, W. (2001). Teoretyczne podstawy terminologii. KJS UW.

Morawski, L. (1980). O pewnym rozumieniu prawa i faktu oraz o niektórych jego zastosowaniach. Ruch Prawniczy, Ekonomiczny i Socjologiczny, $1,185-204$.

Mozgawa, M. (Ed.) (2019). Kodeks karny, komentarz. Wolters Kluwer.

Newmark, P. (1988). A textbook of translation. Prentice Hall.

Pigeon, L.-P. (1982). La rédaction bilingue des lois fédérales. Revue générale de dront, 13, 177-186.

Reiss, K., \& Vermeer, H. (2004). Grundlegung einer allgemeinen Translationstheorie. Max Niemeyer Verlag.

Sager, J.-C. (1996). A practical course in terminology processing. John Benjamins Publishing. 
Šarčevič, S. (1989). Conceptual dictionaries for translation in the field of law. International Journal of Lexicography, 2(4), 277-293.

Šarčevič, S. (1997). New approach to legal translation. Kluwer Law International.

Vinay, J. P., \& Darbelnet, J. (1958/2000). A methodology for translation. In L. Venuti (Ed.), The translation studies reader (pp. 80-89). Routledge.

Weston, M. (1993). An English reader's guide to the French legal system. Berg Publishers Limited.

Wróbel, W. (2014). Kodeks karny Criminal Code przepisy dwujęzyczne. Lex a Wolters Kluwer Business.

\section{Legal Acts}

Council Decision of 25 September 2008 on the conclusion, on behalf of the European Community, of the United Nations Convention against Corruption (2008/801/EC).

Council Decision of 24 July 2006 on the conclusion, on behalf of the European Community, of the Protocol Against the Smuggling of Migrants by Land, Sea and Air, supplementing the United Nations Convention Against Transnational Organised Crime concerning the provisions of the Protocol, in so far as the provisions of this Protocol fall within the scope of Articles 179 and 181a of the Treaty establishing the European Community (2006/616/EC).

The Clean Air Act 1993.

The Criminal Procedure Rules 2012.

The Criminal Procedure (Amendment No. 2) Rules 2013.

The Finance Act 2016.

The Game Act 1831.

The Incitement to Disaffection Act 1934.

The Larceny Act 1916.

The Road Vehicles (Approval) Regulations 2009.

The Teachers' Pensions Regulations 1997.

The Theft Act 1968. 
Ustawa z dnia 6 czerwca 1997 r. - Kodeks karny. Criminal Code Act of 6 June 1997 (Journal of Laws 1997 No. 88 item 553).

\section{Dictionaries}

A dictionary of law (2003). Oxford University Press.

Curzon, L. (2002). Dictionary of law. Pearson Longman.

Jowitt's dictionary of English law (2015). Sweet \& Maxwell.

Osborn's concise law dictionary (2009). Sweet \& Maxwell.

Stroud's judicial dictionary of words and phrases (1951).

Words and phrases legally defined (2007). Red. Hay.

\section{Websites}

Legislation.gov.uk. http:legislation.gov.uk. Consulted on November, 2019;

Database carries most types of legislation of the UK.

Sketchengine.eu. http:sketchengine.eu. Consulted on November, 2019;

Consisting of five hundred corpora each having a size of up to thirty billion words.

\section{Notes}

The article has been produced as a part of the implementation of the Miniatura 2 research project with the register number 2018/02/X/HS2/01602, financed by the National Science Centre (Poland), Varšuvos universitetas, uw.edu.pl. 
Anna Kizińska

Varšuvos universitetas, Lenkija; anna.kizinska@uw.edu.pl

\section{VERTIMO METODAI, TAIKOMI SPRENDŽIANT TERMINU NESUDERINAMUMO KLAUSIMA LENKIJOS IR DIDŽIOSIOS BRITANIJOS BAUDŽIAMOJOJE TEISĖJE}

Santrauka. Tyrime analizuojami nesuderinti Lenkijos ir Didžiosios Britanijos baudžiamosios teisès terminai. Didžiosios Britanijos terminai - tai teisiniu instituciju pavadinimai, egzistuojantys trijose nepriklausomose teisinèse sistemose: Anglijos ir Velso, Škotijos arba Šiaurès Airijos. Aptariami lenkiški terminai buvo surinkti iš $1997 \mathrm{~m}$. birželio 6 d. Lenkijos Respublikos baudžiamojo kodekso (Journal of Laws, 88 (1997), 553). Be to, teisiniu terminu apibrèžimas pateiktas remiantis Morawski'u (1980, p. 187). Analizuojami angliški atitikmenys yra pateikti keturiuose Lenkijos baudžiamojo kodekso vertimuose i anglu kalba. Tyrimo tikslas - patikrinti, ar vertimo metodu, taikomu verčiant nesuderinamus paveldejimo ir šeimos teisès terminus (vadinamus civilinès teisès terminais) iš lenku i anglu kalba, klasifikacija (Kizińska, 2015, p. 175-178) apima vertimo metodus, taikomus verčiant i anglu kalba baudžiamajai teisei būdingus nesuderinamus teisès terminus. Straipsnyje vertimo metodas aiškinamas pagal Hejwowskio (2004, p. 76) apibréžima. Teorineje straipsnio dalyje yra pristatyti šie lingvistiniai fenomenai: terminas (pagal Zmarzer \& Lukszyn, 2001 , p. 9) ir terminu nesuderinamumas (pagal Šarčević, 1989, p. 278). Pradiniame analizès etape buvo palyginti atskiru lenkišku terminu apibréžimai ir pasiūlyti ju atitikmenys. Toliau, siekiant nustatyti vertimo metodus, taikytus formuluojant konkretu atitikmeni, buvo patikrintas konkretaus atitikmens atsiradimas Didžiosios Britanijos teisès tekstu šaltiniuose ir anglu kalboje. Galiausiai buvo sudarytas taikomu vertimo metodu sąrašas. Daroma išvada, kad minètoje vertimo metodu, taikomu verčiant nesuderinamus civilinès teisės terminus iš lenku kalbos i anglu kalba, tipologijoje pateikti vertimo metodai nustatytini tik kaip pirminiai arba tik kaip antriniai.

Pagrindinès sąvokos: civilinè teisè; ekvivalentiškumas; nesuderinami terminai; Lenkijos baudžiamoji teisè; vertimo metodai. 
Anna Kizińska

Uniwersytet Warszawski, Polska; anna.kizinska@uw.edu.pl

\section{METODY TKUMACZENIOWE STOSOWANE W PRZEKŁADZIE NIEPRZYSTAJACYCH TERMINÓW POLSKIEGO I BRYTYJSKIEGO PRAWA KARNEGO}

Streszczenie. Badanie ma na celu omówienie nieprzystających terminów polskich i brytyjskich należących do prawa karnego. Terminy brytyjskie to terminy charakterystyczne dla trzech odrębnych systemów prawnych: Anglii i Walii, Szkocji lub Irlandii Północnej. Analizowane terminy polskie występuja w Ustawie z dnia 6 czerwca 1997 r. Kodeks karny (Dz. U. 1997 Nr 88 poz. 553) i stanowia terminy prawne w rozumieniu Morawskiego (1980, s. 187). Angielskie odpowiedniki każdego analizowanego terminu polskiego zostały zastosowane $\mathrm{w}$ czterech tłumaczeniach polskiego Kodeksu karnego na język angielski. Problem badawczy polega na sprawdzeniu, czy opublikowana klasyfikacja metod tłumaczeniowych stosowanych w polsko-angielskim przekładzie nieprzystających terminów prawa spadkowego i rodzinnego (zwanych terminami cywilnoprawnymi) (Kizińska, 2015, s. 175-178) obejmuje techniki przekładu stosowane $\mathrm{w}$ procesie tłumaczenia nieprzystających terminów prawa karnego na język angielski. Metoda tłumaczeniowa jest rozumiana zgodnie z definicja Hejwowskiego (2004, s. 76). W części teoretycznej omówiono definicję terminu (Zmarzer \& Lukszyn, 2001, s. 9) oraz nieprzystawalności terminów (Šarčević, 1989, s. 278). W początkowej części analizy dokonano porównania definicji danego terminu polskiego i jego sugerowanych ekwiwalentów. Następnie sprawdzono występowanie danego ekwiwalentu w źródłach tekstów prawa brytyjskiego, a także w języku angielskim w celu określenia metod tłumaczeniowych zastosowanych przy tworzeniu danego ekwiwalentu. Na koniec opracowano listę stosowanych metod tłumaczeniowych, aby stwierdzić między innymi, że metody tłumaczeniowe przedstawione $\mathrm{w}$ opublikowanej klasyfikacji metod tłumaczeniowych stosowanych $\mathrm{w}$ polsko-angielskim przekładzie nieprzystających terminów prawa spadkowego i rodzinnego należy określić wyłącznie jako podstawowe lub wtórne.

Słowa kluczowe: prawo cywilne; ekwiwalencja; terminy nieprzystajace; polskie prawo karne; metody tłumaczeniowe. 